\title{
Discovery of Long-Lived Excited Electronic States of Vinylchloride, Vinylbromide, Vinyliodide, and Acrylonitrile Cations
}

\author{
Yeu Young Youn, Joong Chul Choe, ${ }^{1}$ and Myung Soo Kim* \\ National Creative Research Initiative Center for Control of Reaction Dynamics and School of Chemistry, Seoul \\ National University, Seoul, South Korea
}

Charge exchange technique has been used to detect the presence of long-lived excited electronic states of some monosubstituted ethene cations. The technique is based on the criterion that charge exchange between polyatomic species is efficient only when the energy of reaction is close to zero or negative $(\Delta \mathrm{E} \leq 0)$, or the exoergicity rule. The $\tilde{\mathrm{A}}^{2} \mathrm{~A}^{\prime}$ states of vinylchloride, vinylbromide, vinyliodide, and acrylonitrile cations have been found to have long lifetimes (tens of microsecond or longer) while all the excited electronic states of vinylfluoride cation have been found to undergo rapid dissociation or nonradiative relaxation to the ground state. The long-lived states found are those displaying well-resolved vibrational structures in the photoelectron spectra. In particular, these are the states generated by removal of an electron from the in-plane nonbonding $\mathrm{p}$ orbitals of halogens or the in-plane $\pi$ orbital of the triple bond $\mathrm{C} \equiv \mathrm{N}$. The present findings are very similar to those for the monosubstituted benzene cations reported previously. (J Am Soc Mass Spectrom 2003, 14, 110-116) (c) 2003 American Society for Mass Spectrometry

$\mathrm{T}$ Two assumptions made in the theory of mass spectra, or quasi-equilibrium theory (QET), are rapid conversion from excited to ground electronic states for molecular ions generated by the ionization method used and also rapid intramolecular vibrational redistribution in the ground electronic state. Then statistical treatment to evaluate dissociation rate constants becomes equivalent to the Rice-Ramsperger-Kassel-Marcus (RRKM) theory for unimolecular reaction and is often called RRKM-QET [1]. These two hypotheses have been actively investigated over the years, emphasis having been placed more on the latter than the former.

There are some cases where the hypothesis of rapid conversion from an excited to ground electronic states prior to dissociation is not valid. The most frequently observed are the cases of direct dissociation in a repulsive excited electronic state [2-14]. Predissociation via bound-to-repulsive transition has been observed for dissociation of simple molecular cations also [15-18]. Dissociation in a bound excited state, or an "isolated" electronic state, has been hardly observed in ionic cases [19-23]. Hence, searching for isolated electronic states

Published online January 6, 2003

*Address reprint requests to Dr. M. S. Kim, National Creative Research Initiative Center, Seoul National University for Control of Reaction Dynamics and School of Chemistry, Seoul 151-742, South Korea. E-mail: myungsoo@plaza.snu.ac.kr

${ }^{1}$ Permanent address: Department of Chemistry, University of Suwon, Suwon 440-600, South Korea of polyatomic cations remains a mission yet to be fulfilled.

In our recent investigation on photodissociation of benzene cation [24], we found evidences for a very long lifetime (30 $\mu$ s or longer) of its $\tilde{\mathrm{A}}^{2} \mathrm{E}_{2 \mathrm{~g}}$ state. In a subsequent work [25], a method based on charge exchange in collision cells of a modified double focusing mass spectrometer was developed for routine search for long-lived excited states with conventional mass spectrometry. Observations made were summarized as a hypothesis termed the exoergicity rule, which states that an energy resonant $(\Delta \mathrm{E}=0)$ or exoergic $(\Delta \mathrm{E}<0)$ charge exchange occurs efficiently at low collision energy while endoergic one $(\Delta \mathrm{E}>0)$ is hardly observable.

$$
\begin{aligned}
& A^{+}+B \rightarrow A+B^{+}, \Delta E \\
& \Delta E=I E(B)-R E\left(A^{+}\right)
\end{aligned}
$$

Here $\operatorname{RE}\left(\mathrm{A}^{+}\right)$is the recombination energy of $\mathrm{A}^{+}$. RE is equivalent to the ionization energy of the corresponding neutral when $\mathrm{A}^{+}$is in the ground state. Otherwise, it is the sum of the neutral ionization energy and the electronic energy of $\mathrm{A}^{+}$referred to its ground state. By observing the charge exchange signal, $\mathrm{B}^{+}$, from gases with different ionization energies and invoking the exoergicity rule, it is possible to estimate the recombination energy of $\mathrm{A}^{+}$, and hence its electronic energy referred to its ground state. A thorough investigation 


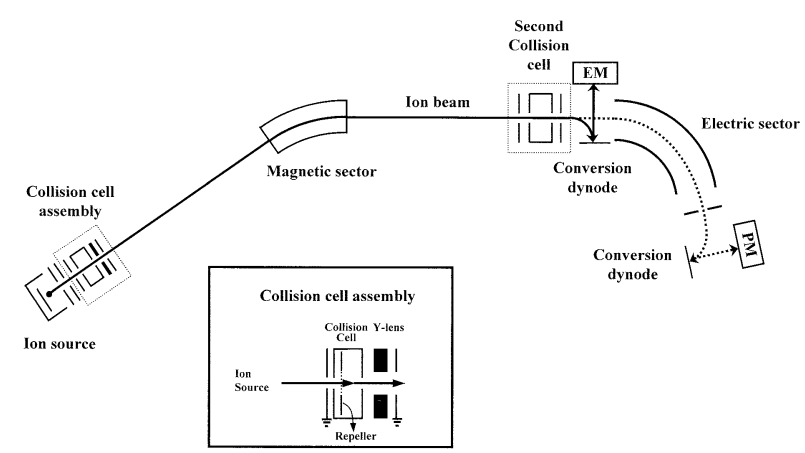

Figure 1. Diagram of the double focusing mass spectrometer with reversed geometry (VG Analytical ZAB-E). The inset shows details of the first charge exchange cell.

showed that reliable estimation of recombination energy was possible with the upper error limit of $+0.1 \mathrm{eV}$ [26]. This validated the exoergicity rule and the method to find ions in long-lived excited electronic state and identify the state involved by charge exchange.

The overall scheme was applied to find long-lived excited electronic states of the molecular ions of some benzene derivatives generated by electron ionization [27]. It was found that the $\tilde{\mathrm{B}}^{2} \mathrm{~B}_{2}$ excited electronic states of chlorobenzene, bromobenzene, benzonitrile, and phenylacetylene cations had very long lifetimes (tens of microsecond or longer). These are the states generated by removal of an electron from the in-plane nonbonding $\mathrm{p}$ orbitals of halogens or in-plane $\pi$ orbitals of the triple bonds. Halogen p orbitals or $\pi$ orbitals of triple bonds in ethene derivatives also split into two just as in the benzene derivatives, one in-plane and the other out-of-plane. Since the situation here is analogous to that for benzene derivatives, the excited electronic states of ethene derivative cations generated by electron removal from the above in-plane orbitals may also have very long lifetimes. Such a possibility has been checked with the charge exchange method and the results are presented in this paper.

\section{Experimental}

A diagram of the double focusing mass spectrometer with reversed geometry (VG Analytical ZAB-E) modified for the present charge exchange study is shown in Figure 1. Details of the experimental method were described previously $[25,27]$. Briefly, sample was introduced to the ion source at $140^{\circ}$ via a glass capillary connected to a reservoir ("septum inlet") and ionized under the electron ionization (EI) condition using $16 \mathrm{eV}$ electron energy. Generation of fragment ions with high recombination energy such as $\mathrm{C}_{2} \mathrm{H}_{2}^{+\cdot}$ in the source was negligible under this condition such that these ions did not interfere with the present measurement. Ions were accelerated with high voltage $\left(\mathrm{V}_{\mathrm{S}}\right)$ of $4 \mathrm{kV}$. Reagent gas for charge exchange was introduced to the collision cell (19 $\mathrm{mm}$ length, see the inset of Figure 1) located between the ion source and the magnetic sector at the pressure of $\sim 5 \times 10^{-4}$ torr. The precursor ion beam was attenuated by $\sim 20 \%$ under this condition, which was the upper limit of the single collision regime [28]. The collision cell was floated at high voltage $\left(\mathrm{V}_{\mathrm{C}}\right)$ such that a precursor ion entering the cell has $30-100 \mathrm{eV}$ translational energy. Alternatively, the precursor ion was selected with the magnetic sector and charge exchange occurring in the collision cell (second cell) located between the magnetic and electric sectors and floated at high voltage $\left(V_{C}^{\prime}\right)$ was observed. Then, ions originating from the charge exchange gas would have the corresponding kinetic energy $\left(\mathrm{eV}_{\mathrm{C}}{ }^{\prime}\right)$ and can be identified by the electric sector even though their exact identity cannot be determined. The second cell experiment, which is complementary to the above first cell one, was also performed in this work.

In a conventional double focusing mass spectrometer, the electric sector potential is set to transmit ions with translational energy $\mathrm{eV}_{\mathrm{S}}$ acquired by acceleration in the ion source. Namely, ions generated from a charge exchange gas in the first cell and accelerated to $\mathrm{eV}_{\mathrm{C}}$ would not be detected in a conventional double focusing operation. We have modified the electronic circuitry of the mass spectrometer such that $\mathrm{eV}_{\mathrm{S}}$ and $\mathrm{eV}_{\mathrm{C}}$ modes are switchable. In the $\mathrm{eV}_{\mathrm{C}}$ mode, only the ions generated from the charge exchange gas can be detected in the double focusing operation.

Vinyliodide and vinylfluoride were purchased from Lancaster (Lancashire, UK) and other chemicals from Aldrich (Milwaukee, WI). All the chemicals were of the highest purity commercially available and were used without further purification.

\section{Results and Discussion}

Lifetime of an excited state can sometimes be estimated from the spectral width. However, there has been no report on the optical spectra of the molecular cations investigated here. The only spectral data available for these cations are the photoelectron spectra (PES) which are not adequate for lifetime estimation due to broad instrumental width $\left(\sim 80 \mathrm{~cm}^{-1}\right.$ or larger $)$ inherent in the technique. Indication for a possibly very long lifetime of an excited electronic state can be found in these low resolution spectra, however, because a long lifetime (tens of microsecond) would not affect the spectral width such that widths of vibrational peaks from these states would be essentially the same as those from the ground state. The photoelectron spectra of $\mathrm{C}_{2} \mathrm{H}_{3} \mathrm{X}(\mathrm{X}=$ $\mathrm{F}, \mathrm{Cl}, \mathrm{Br}, \mathrm{I}$, and $\mathrm{CN}$ ) were reported previously [29-32]. The instrumental resolution adopted was relatively high for $\mathrm{C}_{2} \mathrm{H}_{3} \mathrm{Cl}, \mathrm{C}_{2} \mathrm{H}_{3} \mathrm{Br}$, and $\mathrm{C}_{2} \mathrm{H}_{3} \mathrm{CN}$ (acrylonitrile) while rather poor for $\mathrm{C}_{2} \mathrm{H}_{3} \mathrm{~F}$ and $\mathrm{C}_{2} \mathrm{H}_{3} \mathrm{I}$. In all the cases except $\mathrm{C}_{2} \mathrm{H}_{3} \mathrm{I}$, the bands appearing at the lowest ionization energy are those arising from removal of an electron from the $\pi(\mathrm{C}=\mathrm{C})$ orbital. In the case of $\mathrm{C}_{2} \mathrm{H}_{3} \mathrm{I}$, the first band is due to electron removal from the out-ofplane iodine nonbonding $\mathrm{p}$ orbital $\left(\mathrm{p}_{\perp}\right)$ [29]. In all the cases, the ground states of the molecular cations are 
Table 1. Recombination energies ${ }^{a}$ of the $\tilde{\mathrm{X}}^{2} \mathrm{~A}^{\prime \prime}, \tilde{\mathrm{A}}^{2} \mathrm{~A}^{\prime}$, and $\tilde{\mathrm{B}}$ electronic states of the monosubstituted ethene cations investigated and the calculated oscillator strengths ${ }^{\mathrm{b}}$ for the $\tilde{\mathrm{A}}^{2} \mathrm{~A}^{\prime} \rightarrow \tilde{\mathrm{X}}^{2} \mathrm{~A}^{\prime \prime}$ radiative transitions

\begin{tabular}{lcccrc}
\hline State $^{\mathrm{c}}$ & $\mathrm{C}_{2} \mathrm{H}_{3} \mathrm{~F}^{+\cdot}$ & $\mathrm{C}_{2} \mathrm{H}_{3} \mathrm{Cl}^{+\cdot}$ & $\mathrm{C}_{2} \mathrm{H}_{3} \mathrm{Br}^{+\cdot}$ & $\mathrm{C}_{2} \mathrm{H}_{3} \mathrm{I}^{+\cdot}$ & $\mathrm{C}_{2} \mathrm{H}_{3} \mathrm{CN}^{+\cdot}$ \\
\hline \hline$\tilde{\mathrm{X}}^{2} \mathrm{~A}^{\prime \prime}$ & 10.57 & 10.005 & 9.804 & 9.26 & 10.91 \\
$\tilde{\mathrm{A}}^{2} \mathrm{~A}^{\prime}$ & 13.80 & 11.664 & 10.899 & 10.04 & 12.36 \\
$\tilde{\mathrm{B}}^{2} \mathrm{~A}^{\prime \prime}\left(\mathrm{A}^{\prime}\right)$ & 14.60 & 13.13 & 12.27 & 11.50 & 13.04 \\
For $\tilde{\mathrm{A}}^{2} \mathrm{~A}^{\prime} \rightarrow \tilde{\mathrm{X}}^{2} \mathrm{~A}^{\prime \prime}$ & & & & $4 \times 10^{-6}$ & $1.1 \times 10^{-5}$ \\
Oscillator strength & $1.9 \times 10^{-4}$ & $1.5 \times 10^{-5}$ & $7 \times 10^{-6}$ & $4 \times 0$ \\
Radiative lifetime ( $\mu \mathrm{sec})$ & 10 & 470 & 2300 & 11000 \\
\hline
\end{tabular}

aTaken from references 29, 30, 31, 29 and 32 for $\mathrm{C}_{2} \mathrm{H}_{3} \mathrm{~F}^{+*}, \mathrm{C}_{2} \mathrm{H}_{3} \mathrm{Cl}^{+*}, \mathrm{C}_{2} \mathrm{H}_{3} \mathrm{Br}^{+*}, \mathrm{C}_{2} \mathrm{H}_{3} \mathrm{I}^{+}$, and $\mathrm{C}_{2} \mathrm{H}_{3} \mathrm{CN}^{+*}$, respectively. In eV.

${ }^{b}$ Results from TDDFT/UB3LYP calculations with the $6-31 \mathrm{G}^{* *}$ basis set. The LanL2DZ basis set was used for the iodine atom.

${ }^{c}$ The third doublet state is $\tilde{B}^{2} \mathrm{~A}^{\prime}$ for $\mathrm{C}_{2} \mathrm{H}_{3} \mathrm{~F}^{+\cdot}$ and $\tilde{B}^{2} \mathrm{~A}^{\prime \prime}$ for others.

$\tilde{\mathrm{X}}^{2} \mathrm{~A}$. These are followed by the peaks due to removal of an electron from the in-plane halogen nonbonding $p$ orbital $\left(\mathrm{p}_{\|}\right)$for halides and from the in-plane $\pi(\mathrm{C} \equiv \mathrm{N})_{\|}$ orbital, or $\pi(\mathrm{C} \equiv \mathrm{N})_{\|}$for $\mathrm{C}_{2} \mathrm{H}_{3} \mathrm{CN}$, all of which correspond to the $\tilde{\mathrm{A}}^{2} \mathrm{~A}$ ' states of the cations. In the high resolution photoelectron spectra of $\mathrm{C}_{2} \mathrm{H}_{3} \mathrm{Cl}$ [30], $\mathrm{C}_{2} \mathrm{H}_{3} \mathrm{Br}$ [31], and $\mathrm{C}_{2} \mathrm{H}_{3} \mathrm{CN}$ [32], both of these bands show well resolved vibrational structures with nearly the same vibrational peak widths. The lifetimes estimated from these widths if the observed PES peak widths correspond purely to lifetime broadening of the excited state, without taking into account the actual additional contributions to these widths by instrumental broadening and the presence of rotational structure, the lifetimes implied by the widths would be in the high femtosecond range. Namely, the fact that the vibrational peak widths of the $\tilde{\mathrm{A}}^{2} \mathrm{~A}^{\prime}$ states in the photoelectron spectra are similar to those of the ground states is not the proof, even though an indication, for the long lifetimes of the former states. Sharp vibrational features are observed also for the $\tilde{\mathrm{X}}^{2} \mathrm{~A}^{\prime \prime}$ bands of $\mathrm{C}_{2} \mathrm{H}_{3} \mathrm{~F}$ and the $\tilde{\mathrm{X}}^{2} \tilde{\mathrm{A}}^{\prime \prime}$ and $\tilde{\mathrm{A}}^{2} \mathrm{~A}^{\prime}$ bands of $\mathrm{C}_{2} \mathrm{H}_{3} \mathrm{I}$ in the low resolution photoelectron spectra.

Characters of the third photoelectron bands differ for different molecules. These are due to removal of a $\sigma(\mathrm{CF})$ electron for $\mathrm{C}_{2} \mathrm{H}_{3} \mathrm{~F}$, a halogen $\mathrm{p}_{\perp}$ electron for $\mathrm{C}_{2} \mathrm{H}_{3} \mathrm{Cl}$ and $\mathrm{C}_{2} \mathrm{H}_{3} \mathrm{Br}$, a $\pi(\mathrm{C}=\mathrm{C})$ electron for $\mathrm{C}_{2} \mathrm{H}_{3} \mathrm{I}$, and an out-of-plane $\pi(\mathrm{C} \equiv \mathrm{N})$, or $\pi(\mathrm{C} \equiv \mathrm{N})_{\perp}$, electron for $\mathrm{C}_{2} \mathrm{H}_{3} \mathrm{CN}$. The ionic states corresponding to the third bands can be denoted $\tilde{\mathrm{B}}^{2} \mathrm{~A}^{\prime}$ for $\mathrm{C}_{2} \mathrm{H}_{3} \mathrm{~F}^{+\cdot}$ and $\tilde{\mathrm{B}}^{2} \mathrm{~A}^{\prime \prime}$ for all the others. The $\tilde{\mathrm{A}}^{2} \mathrm{~A}^{\prime}$ band of $\mathrm{C}_{2} \mathrm{H}_{3} \mathrm{~F}$ and the $\tilde{\mathrm{B}}$ or higher bands of all the molecules investigated here, except the $\tilde{\mathrm{B}}$ band of $\mathrm{C}_{2} \mathrm{H}_{3} \mathrm{CN}$, appear as broad structurless features in the photoelectron spectra. Hence, investigation of the PES band structures suggests the $\tilde{\mathrm{A}}^{2} \mathrm{~A}^{\prime}$ states of $\mathrm{C}_{2} \mathrm{H}_{3} \mathrm{Cl}^{+*}$, $\mathrm{C}_{2} \mathrm{H}_{3} \mathrm{Br}^{+\cdot}, \mathrm{C}_{2} \mathrm{H}_{3} \mathrm{I}^{+\cdot}$, and $\mathrm{C}_{2} \mathrm{H}_{3} \mathrm{CN}^{+\cdot}$ and the $\tilde{\mathrm{B}}^{2} \mathrm{~A}^{\prime \prime}$ state of $\mathrm{C}_{2} \mathrm{H}_{3} \mathrm{CN}^{+\cdot}$ as the candidates for excited electronic states with very long lifetimes. Recombination energies of the $\tilde{\mathrm{X}}^{2} \mathrm{~A}^{\prime \prime}, \tilde{\mathrm{A}}^{2} \mathrm{~A}^{\prime}$, and $\tilde{\mathrm{B}}$ electronic states of $\mathrm{C}_{2} \mathrm{H}_{3} \mathrm{X}^{+\cdot}(\mathrm{X}=\mathrm{F}$, $\mathrm{Cl}, \mathrm{Br}, \mathrm{I}$, and $\mathrm{CN}$ ) are listed in Table 1.

As was mentioned in our previous work [25], three types (I, II, and III) of ions appear in the mass spectrum obtained by scanning the magnetic sector with charge exchange gas in the collision cell floated at high voltage $\left(V_{C}\right)$. These are ions generated in the ion source (type I), their collision-induced dissociation products (type II) generated in the collision cell, and ions originating from the charge exchange gas (type III). Taking $\mathrm{V}_{\mathrm{S}}$ as the acceleration voltage in the ion source, the translational energies after exiting the collision cell can be expressed as follows.

$$
\begin{aligned}
& \text { Type I, } K_{I}=e V_{S} \\
& \text { Type II, } K_{I I}=e\left[V_{C}+\left(m_{2} / m_{1}\right)\left(V_{S}-V_{C}\right)\right] \\
& \text { Type III, } K_{I I I}=e V_{C}
\end{aligned}
$$

In eq $4, m_{1}$ and $m_{2}$ are masses of the precursor and fragment ions, respectively, in the collision-induced dissociation. In an ordinary mass spectrum recorded by a single focusing mass spectrometer, the following relation holds for the $\mathrm{m} / \mathrm{z}$ of an ion transmitted with the magnetic field (B), its radius ( $\mathrm{r}$ ), and the acceleration voltage $\left(\mathrm{V}_{\mathrm{S}}\right)$ [33].

$$
m / z=B^{2} r^{2} e / 2 V_{S}
$$

Since the translational energies of type II and III ions differ from that of the ordinary ions (type I), they will not appear at their ordinary $\mathrm{m} / \mathrm{z}$ positions in the spectrum. Measuring their effective $m / z$ positions and analyzing with eqs $4-6$, their correct $m / z$ values can be obtained. Classification of ions into the three types can be further confirmed by changing $\mathrm{V}_{\mathrm{C}}$, tracking their positions in the mass spectrum, and comparing the results with calculations using eqs 3-6. Type I and II ions appearing in the single focusing spectrum can be eliminated by double focusing operation with the electric sector potential set to transmit ions with kinetic energy $\mathrm{eV}_{\mathrm{C}}$ and the magnetic sector scanned. Then, the following relation holds for type III ions appearing in the double focusing spectrum.

$$
m / z=B^{2} r^{2} e / 2 V_{C}
$$

Ionization energies of charge exchange gases used are listed in Table 2. For each candidate ion, some of the charge exchange gases in the table were chosen as needed. 
Table 2. Charge exchange gases, their ionization energies (IE) in $\mathrm{eV}$, and success/failure ${ }^{a}$ to observe charge exchange signals for some precursor ion/charge exchange gas combinations

\begin{tabular}{|c|c|c|c|c|c|c|c|}
\hline \multirow{2}{*}{$\begin{array}{l}\text { Charge exchange } \\
\text { gas }\end{array}$} & \multirow[b]{2}{*}{$\mathrm{IE}$} & \multirow[b]{2}{*}{ Ref. } & \multicolumn{5}{|c|}{ Precursor ions } \\
\hline & & & $\mathrm{C}_{2} \mathrm{H}_{3} \mathrm{~F}^{+\cdot}$ & $\mathrm{C}_{2} \mathrm{H}_{3} \mathrm{Cl}^{+\cdot}$ & $\mathrm{C}_{2} \mathrm{H}_{3} \mathrm{Br}^{+\cdot}$ & $\mathrm{C}_{2} \mathrm{H}_{3} \mathrm{I}^{+\cdot}$ & $\mathrm{C}_{2} \mathrm{H}_{3} \mathrm{CN}^{+\cdot}$ \\
\hline $1,3-\mathrm{C}_{4} \mathrm{H}_{6}$ (butadiene) & $9.072 \pm 0.007$ & 34 & 0 & $\mathrm{O}$ & 0 & 0 & \\
\hline $\mathrm{CH}_{2}=\mathrm{C}=\mathrm{CH}$ (allene) & $9.691 \pm 0.004$ & 36 & & & & $\mathrm{O}$ & \\
\hline $\mathrm{C}_{2} \mathrm{H}_{3} \mathrm{Cl}$ & 10.005 & 30 & & & & 0 & \\
\hline $\mathrm{CS}_{2}$ & 10.07 & 34 & & & $\mathrm{O}$ & & \\
\hline $\mathrm{CH}_{3} \mathrm{Br}$ & $10.54 \pm 0.01$ & 37 & $\mathrm{O}$ & $\mathrm{O}$ & $\mathrm{O}$ & $x$ & $\mathrm{O}$ \\
\hline $\mathrm{C}_{2} \mathrm{H}_{5} \mathrm{Cl}$ & $10.98 \pm 0.02$ & 38 & $x$ & & & $x$ & \\
\hline $\mathrm{CH}_{3} \mathrm{Cl}$ & $11.28 \pm 0.01$ & 39 & $x$ & $\mathrm{O}$ & $x$ & & $\mathrm{O}$ \\
\hline $\mathrm{Xe}$ & $12.12 \pm 0.01$ & 40 & & $x$ & $x$ & & $\mathrm{O}$ \\
\hline $\mathrm{CH}_{3} \mathrm{~F}$ & 12.50 & 41 & $\mathrm{X}$ & $x$ & & & $X$ \\
\hline $\mathrm{CHF}_{3}$ & 13.86 & 34 & $x$ & & & & $x$ \\
\hline
\end{tabular}

a Success and failure indicated by $\mathrm{O}$ and $\mathrm{X}$, respectively. Symbols are not drawn when experiments were not done.

Figure 2 shows the mass spectra of $\mathrm{C}_{2} \mathrm{H}_{3} \mathrm{Cl}$ recorded with $\mathrm{CH}_{3} \mathrm{Cl}$ in the collision cell. Since $\mathrm{V}_{\mathrm{S}}$ and $\mathrm{V}_{\mathrm{C}}$ were 4050 and $4004 \mathrm{~V}$, respectively, the translational energy of $\mathrm{C}_{2} \mathrm{H}_{3} \mathrm{Cl}^{+\cdot}$ in the charge exchange cell, or collision energy, was $46 \mathrm{eV}$. Even though $\mathrm{C}_{2} \mathrm{H}_{3}^{+}$is also generated by $16 \mathrm{eV}$ electron ionization as can be seen in the single focusing spectrum, Figure $2 \mathrm{a}$, this does not affect the present measurement because its recombination energy of $8.25 \mathrm{eV}$ [34] is lower than that of $\mathrm{C}_{2} \mathrm{H}_{3} \mathrm{Cl}^{+\cdot}$ in the ground state. Following the procedure described above, the peak appearing at $\mathrm{m} / \mathrm{z} 49.4$ in the single focusing spectrum was identified as type III ion of $\mathrm{CH}_{3}^{35} \mathrm{Cl}^{+*}$. The spectrum recorded by $\mathrm{eV}_{\mathrm{C}}$ double focusing operation is shown in Figure $2 \mathrm{~b}$. It is to be noted that all the type I peaks disappeared and only type III peaks are present in this spectrum. In addition to $\mathrm{CH}_{3} \mathrm{Cl}^{+}, \mathrm{CH}_{2} \mathrm{Cl}^{+}$and
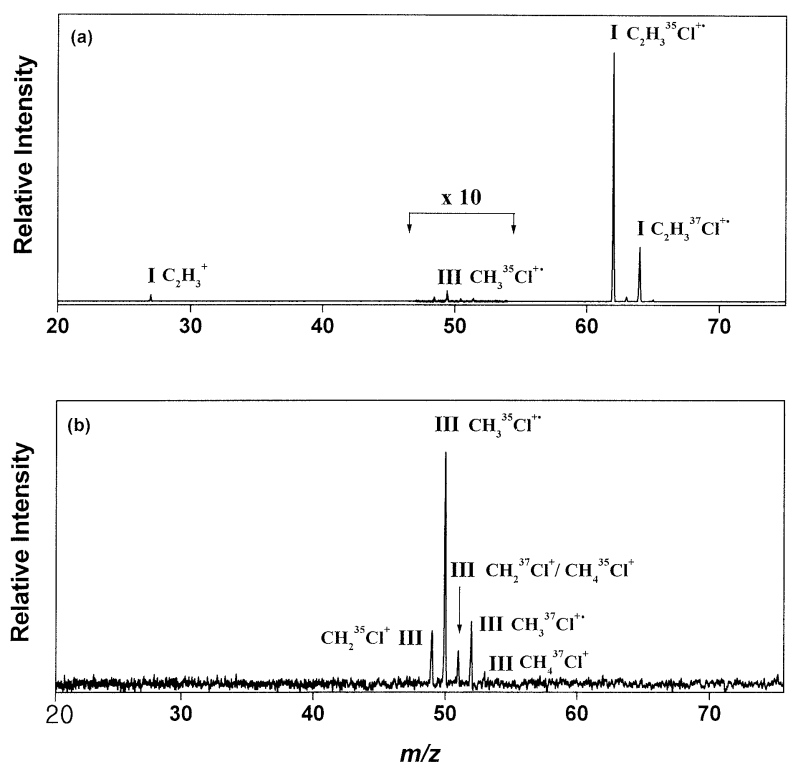

Figure 2. Mass spectra of $\mathrm{C}_{2} \mathrm{H}_{3} \mathrm{Cl}$ generated by $16 \mathrm{eV}$ EI recorded with $\mathrm{CH}_{3} \mathrm{Cl}$ in the collision cell floated at $4004 \mathrm{~V}$. The acceleration energy in the ion source was $4050 \mathrm{eV}$. (a) and (b) show mass spectra recorded by single and $\mathrm{eV}_{\mathrm{C}}$ double focusing operations, respectively. The $\mathrm{m} / \mathrm{z}$ scales in (a) and (b) were calculated using eqs 6 and 7, respectively.
$\mathrm{CH}_{4} \mathrm{Cl}^{+}$also appear in this spectrum which can be the products of ion-molecule reactions occurring in the cell [35]. Ionization energy of $\mathrm{CH}_{3} \mathrm{Cl}$ is $11.28 \pm 0.01 \mathrm{eV} \mathrm{[39].}$ Invoking the exoergicity rule, we can conclude from the distinct appearance of charge exchange signals that an ionic species with recombination energy equal to or larger than $11.28 \mathrm{eV}$ is present in the ion beam entering the charge exchange cell. It is to be emphasized that $\mathrm{C}_{2} \mathrm{H}_{3} \mathrm{Cl}^{+\cdot}$ in the ground electronic state $(\mathrm{RE}=10.005$ eV) cannot ionize $\mathrm{CH}_{3} \mathrm{Cl}$ by charge exchange. We also attempted but failed to record charge exchange signals from Xe (IE = $12.12 \pm 0.01 \mathrm{eV})[40]$ and $\mathrm{CH}_{3} \mathrm{~F}(\mathrm{IE}=$ $12.50 \mathrm{eV}$ ) [41] at the same collision energy. Referring to the data in Table 1, the above eliminates the $\tilde{\mathrm{B}}$ or higher excited electronic states of $\mathrm{C}_{2} \mathrm{H}_{3} \mathrm{Cl}^{+\cdot}$ as the states responsible for charge exchange with $\mathrm{CH}_{3} \mathrm{Cl}$. The $\tilde{\mathrm{A}}^{2} \mathrm{~A}$ ' state is the only electronic state of $\mathrm{C}_{2} \mathrm{H}_{3} \mathrm{Cl}^{+\cdot}$ with the recombination energy in the range from $11.28 \mathrm{eV}$ $\left(\mathrm{CH}_{3} \mathrm{Cl}\right.$ charge exchange) to $12.12 \mathrm{eV}$ (Xe charge exchange) and is identified as the long-lived state involved in the charge exchange with $\mathrm{CH}_{3} \mathrm{Cl}$. Also to be mentioned is that all the electronic states lying above the $\tilde{\mathrm{A}}$ state do not have lifetimes long enough to survive until $\mathrm{C}_{2} \mathrm{H}_{3} \mathrm{Cl}^{+\cdot}$ enters the charge exchange cell which takes $2-3 \mu$ s after its formation, either due to rapid dissociation or due to rapid relaxation. This is in agreement with prediction from the photoelectron spectrum.

Figure 3 shows the mass spectra obtained by $\mathrm{eV}_{\mathrm{C}}$ double focusing operation for $\mathrm{C}_{2} \mathrm{H}_{3} \mathrm{Br}(3 \mathrm{a}), \mathrm{C}_{2} \mathrm{H}_{3} \mathrm{I}(3 \mathrm{~b})$, and $\mathrm{C}_{2} \mathrm{H}_{3} \mathrm{CN}$ (3c). Charge exchange gases used were $\mathrm{CH}_{3} \mathrm{Br}$ (IE = $10.54 \pm 0.01 \mathrm{eV}$ ) [37], $\mathrm{CH}_{2}=\mathrm{C}=\mathrm{CH}_{2}$ (IE = $9.691 \pm 0.01 \mathrm{eV})[36]$, and $\mathrm{Xe}(\mathrm{IE}=12.12 \pm 0.01 \mathrm{eV})[40]$, respectively. Appearance of prominent type III signals in these spectra recorded at low collision energy (30-50 $\mathrm{eV})$ suggests electronically exoergic charge exchanges occurring in these cases. We also carried out experiments using charge exchange gases with widely different ionization energies. Charge exchange signals either appeared prominently or did not appear at all depending on the precursor ion/charge exchange gas combinations investigated. Success or failure to observe a 

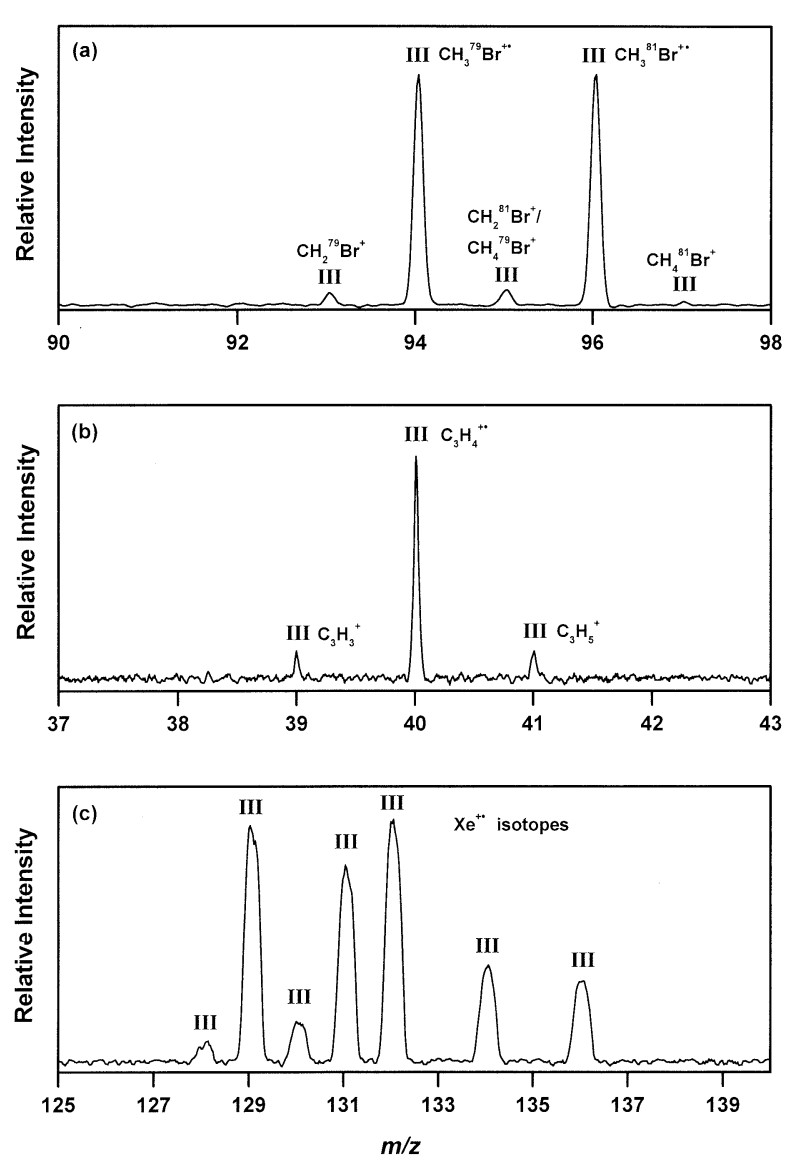

Figure 3. Partial mass spectra obtained by $\mathrm{eV}_{\mathrm{C}}$ double focusing operations for (a) $\mathrm{C}_{2} \mathrm{H}_{3} \mathrm{Br}$ with $\mathrm{CH}_{3} \mathrm{Br}$ charge exchange gas, (b) $\mathrm{C}_{2} \mathrm{H}_{3} \mathrm{I}$ with $\mathrm{CH}_{2}=\mathrm{C}=\mathrm{CH}_{2}$ charge exchange gas, and (c) $\mathrm{C}_{2} \mathrm{H}_{3} \mathrm{CN}$ with Xe charge exchange gas. $4004 \mathrm{~V}$ was applied to the charge exchange cell. The acceleration energy in the source was (a) 4036, (b) 4050 , and (c) $4045 \mathrm{eV}$. The $\mathrm{m} / \mathrm{z}$ scale was calculated using eq 7 .

charge exchange signal for the combinations investigated is summarized in Table 2. Interpretation of these data with the exoergicity rule means that long-lived electronic states with recombination energies in the ranges of 10.54-10.98, 10.54-11.28, 10.005-10.54, and 12.12-12.50 eV for $\mathrm{C}_{2} \mathrm{H}_{3} \mathrm{~F}^{+*}, \mathrm{C}_{2} \mathrm{H}_{3} \mathrm{Br}^{+*}, \mathrm{C}_{2} \mathrm{H}_{3} \mathrm{I}^{+*}$, and $\mathrm{C}_{2} \mathrm{H}_{3} \mathrm{CN}^{+*}$, respectively, contribute to the observed signals. These are the $\tilde{X}^{2} \mathrm{~A}^{\prime \prime}$ state in the case of $\mathrm{C}_{2} \mathrm{H}_{3} \mathrm{~F}^{+\cdot}$ and $\tilde{\mathrm{A}}^{2} \mathrm{~A}^{\prime}$ states for all the others. Namely, the $\tilde{\mathrm{A}}^{2} \mathrm{~A}^{\prime}$ excited electronic states of $\mathrm{C}_{2} \mathrm{H}_{3} \mathrm{X}^{+\cdot}$ generated by removal of a $\mathrm{p}_{\|}$or $\pi(\mathrm{C} \equiv \mathrm{N})_{\|}$electron are long-lived with the exception of $\mathrm{C}_{2} \mathrm{H}_{3} \mathrm{~F}^{+\cdot}$. The $\tilde{\mathrm{A}}^{2} \mathrm{~A}^{\prime}$ state of $\mathrm{C}_{2} \mathrm{H}_{3} \mathrm{~F}^{+\cdot}$ and the $\tilde{\mathrm{B}}$ or higher states in all the cases relax or dissociate rapidly and hence do not contribute to the charge exchange signals. This is as predicted from the broad structureless features of the corresponding bands in the photoelectron spectra. Also to be noted is that the $\tilde{\mathrm{B}}^{2} \mathrm{~A}^{\prime \prime}$ state of $\mathrm{C}_{2} \mathrm{H}_{3} \mathrm{CN}^{+\cdot}$ is not long-lived even though the corresponding band is sharp in the photoelectron spectrum.

We also performed similar experiments using a collision cell located between the magnetic and electric sectors, or the second cell. This was done to eliminate any possible complication involved in the first cell
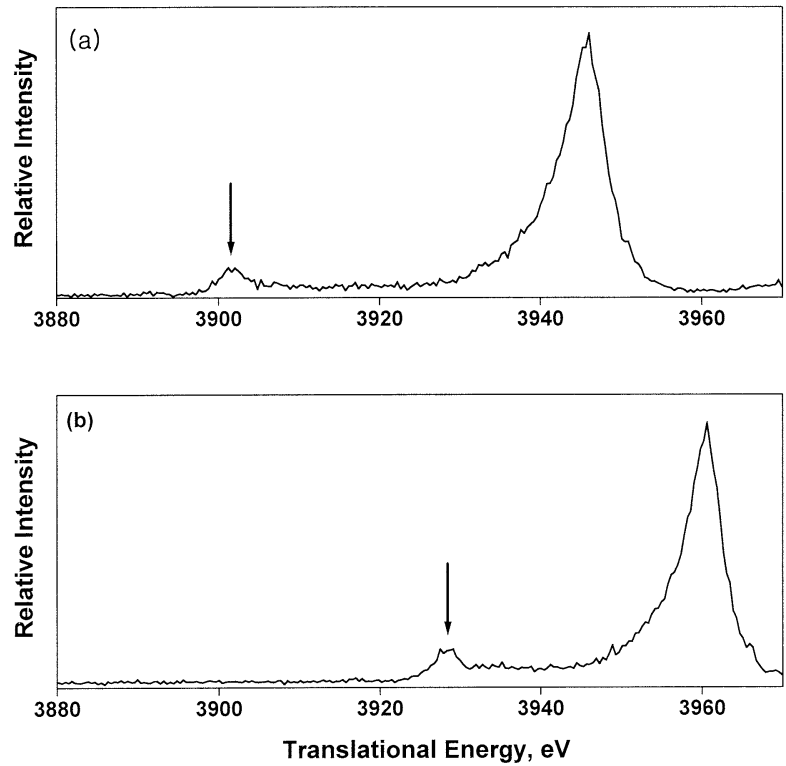

Figure 4. Ion kinetic energy spectra recorded by introducing $\mathrm{C}_{2} \mathrm{H}_{3} \mathrm{Cl}^{+\cdot}$ into the second cell filled with $\mathrm{CH}_{3} \mathrm{Cl}$. The molecular ions were accelerated to $4 \mathrm{keV}$ in the ion source. The second collision cell was floated at (a) 3902 and (b) 3928 V. Arrows indicate the expected positions for ions from $\mathrm{CH}_{3} \mathrm{Cl}$ generated by charge exchange with the precursor ions. The major peaks appearing at 3946 and $3961 \mathrm{eV}$ in (a) and (b), respectively, are due to collision-induced dissociation of $\mathrm{C}_{2} \mathrm{H}_{3} \mathrm{Cl}^{+\cdot}$ to $\mathrm{C}_{2} \mathrm{H}_{3}^{+}$.

experiment, such as the charge exchange gas leak into the source. The second cell experiment is also useful to estimate the lower limit of the lifetime of a long-lived state. Molecular ions generated in the source were accelerated to $4 \mathrm{keV}$, mass-selected by the magnetic sector, and decelerated to $50-100 \mathrm{eV}$ by floating the cell at 3900-3950 V. Figure 4 shows the ion kinetic energy spectra obtained by introducing vinylchloride cation to the second cell filled with $\mathrm{CH}_{3} \mathrm{Cl}$ and scanning the electric sector potential. Arrows in the spectra indicate the kinetic energy corresponding to the cell potential, or ions originating from the collision cell. A peak appeared at this position and moved with the cell potential when vinylchloride cation was introduced into the cell as demonstrated in this figure. This is in agreement with the first cell result that $\mathrm{CH}_{3} \mathrm{Cl}$ is ionized by vinylchloride cation in the long-lived state. The time between vinylchloride cation formation in the ion source and its arrival at the second cell is $\sim 25 \mu$ s. Then, the above observation means that some of the vinylchloride cations in the $\tilde{\mathrm{A}}^{2} \mathrm{~A}$ ' state have survived as long as $25 \mu \mathrm{s}$. We also performed similar experiments for the other cations. Since the results were in agreement with those of the first cell experiments, no further spectra will be presented.

It would be very interesting to know what fraction of $\mathrm{C}_{2} \mathrm{H}_{3} \mathrm{X}^{+\cdot}(\mathrm{X}=\mathrm{Cl}, \mathrm{Br}, \mathrm{I}$, and $\mathrm{CN})$ entering the first or second collision cell would be in the long-lived $\tilde{\mathrm{A}}^{2} \mathrm{~A}^{\prime}$ state. From the threshold photoelectron and constant ion state spectra of $\mathrm{C}_{2} \mathrm{H}_{3} \mathrm{Cl}$ reported by Locht et al. [30], one speculates that a few ten percent of $\mathrm{C}_{2} \mathrm{H}_{3} \mathrm{Cl}^{+}$. 
generated by $16 \mathrm{eV}$ electron ionization are in the $\tilde{\mathrm{A}}^{2} \mathrm{~A}^{\prime}$ state. A rough estimation based on the intensities of the parent ion and charge exchange ion signals observed in this experiment suggests that the fraction of $\mathrm{C}_{2} \mathrm{H}_{3} \mathrm{X}^{+}$. $(\mathrm{X}=\mathrm{Cl}, \mathrm{Br}, \mathrm{I}$, and $\mathrm{CN})$ in the $\tilde{\mathrm{A}}^{2} \mathrm{~A}^{\prime}$ state is on the order of $10 \%$. An experimental scheme is being designed for this purpose.

For an excited electronic state to have a very long lifetime (tens of microsecond or longer), neither radiative decay nor nonradiative decay should be efficient. Even though efficiency of the latter is not easy to investigate, that of the former can be estimated through the symmetry selection rule and calculation of the oscillator strength. For $\mathrm{C}_{2} \mathrm{H}_{3} \mathrm{X}^{+\cdot}(\mathrm{X}=\mathrm{Cl}, \mathrm{Br}, \mathrm{I}$, and $\mathrm{CN})$, there is only one electronic state, namely the ground state $\tilde{\mathrm{X}}^{2} \mathrm{~A}^{\prime \prime}$, lying below the long-lived excited states $\tilde{\mathrm{A}}^{2} \mathrm{~A}^{\prime}$. It is to be noted that the electric dipole transition $\tilde{\mathrm{A}}^{2} \mathrm{~A}^{\prime} \rightarrow \tilde{\mathrm{X}}^{2} \mathrm{~A}^{\prime \prime}$ is symmetry allowed. Then, its oscillator strength must be very small for the radiative decay to be ineffective. In this regard, the oscillator strengths were calculated with the GAUSSIAN 98 package [42]. Geometries of $\mathrm{C}_{2} \mathrm{H}_{3} \mathrm{X}^{+\cdot}(\mathrm{X}=\mathrm{F}, \mathrm{Cl}, \mathrm{Br}$, and $\mathrm{CN})$ in the ground electronic states were optimized at the UB3LYP/6$31 \mathrm{G}^{* *}$ level and oscillator strengths were obtained through the time-dependent density functional theory (TDDFT) calculation. A correction has been made for the error in the original software. In the case of $\mathrm{C}_{2} \mathrm{H}_{3} \mathrm{I}^{+}$, the $6-31 G^{* *}$ basis set was also used except for the iodine atom for which the LanL2DZ basis set was used. The oscillator strengths and radiative lifetimes for the $\tilde{\mathrm{A}}^{2} \mathrm{~A}^{\prime}$ $\rightarrow \tilde{\mathrm{X}}^{2} \mathrm{~A}^{\prime \prime}$ transitions thus obtained are listed in Table 1 . The calculated radiative lifetimes are several hundred $\mu$ s or longer for $\mathrm{C}_{2} \mathrm{H}_{3} \mathrm{X}^{+\cdot}(\mathrm{X}=\mathrm{Cl}, \mathrm{Br}, \mathrm{I}$, and $\mathrm{CN})$. The calculated radiative lifetime for this transition in $\mathrm{C}_{2} \mathrm{H}_{3} \mathrm{~F}^{+}$, $10 \mu \mathrm{s}$, is shorter than others and is on the same order of magnitude as the flight time to the first cell from its formation in the ion source, 2-3 $\mu \mathrm{s}$. According to a photoelectron-photoion coincidence study [5], $\mathrm{C}_{2} \mathrm{H}_{3} \mathrm{~F}^{+\cdot}$ ions generated in the $\tilde{\mathrm{A}}^{2} \mathrm{~A}^{\prime}$ state undergo dissociation in the ground state. Hence, rapid $\tilde{\mathrm{A}}^{2} \mathrm{~A}^{\prime} \rightarrow \tilde{\mathrm{X}}^{2} \mathrm{~A}^{\prime \prime}$ internal conversion, rather than radiative decay, seems to be the main relaxation mechanism in this case. Rapid relaxation of this state is compatible with the present experimental results. We do not have a clear explanation at the moment, however, why the $\tilde{\mathrm{A}}^{2} \mathrm{~A}^{\prime}$ state of $\mathrm{C}_{2} \mathrm{H}_{3} \mathrm{~F}^{+}$. relaxes rapidly while those of the others do not.

We also calculated the lowest energy doublet and quartet states with an electron in the lowest unoccupied molecular orbital (LUMO) of $\mathrm{C}_{2} \mathrm{H}_{3} \mathrm{X}^{+\cdot}(\mathrm{X}=\mathrm{Cl}, \mathrm{Br}, \mathrm{I}$, and $\mathrm{CN})$ at the TDDFT/UB3LYP level. This was to check the possibility that proximity of these states to the $\tilde{\mathrm{A}}^{2} \mathrm{~A}^{\prime}$ states would affect the lifetime of the latter states. The lowest doublet states with an electron in LUMO were found at 5.51, 5.29, 4.99, and $5.00 \mathrm{eV}$ (vertical energies) above the ground states while the lowest quartet states were found at 5.13, 4.76, 4.35, and $4.10 \mathrm{eV}$ (adiabatic energies) above the ground states of $\mathrm{C}_{2} \mathrm{H}_{3} \mathrm{X}^{+\cdot}(\mathrm{X}=\mathrm{Cl}$, $\mathrm{Br}, \mathrm{I}$, and $\mathrm{CN})$, respectively. Namely, all these states were found to be located substantially above the $\tilde{\mathrm{A}}^{2} \mathrm{~A}^{\prime}$

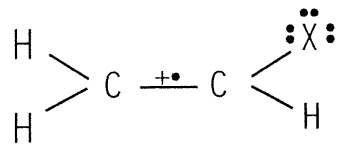

$\widetilde{\mathrm{X}}$
$\widetilde{\mathrm{A}}$

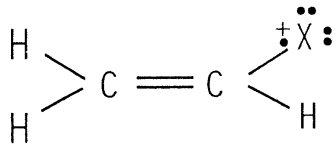

Structure 1

states and are not expected to affect the $\tilde{\mathrm{A}}^{2} \mathrm{~A}^{\prime}$ state lifetimes.

Finally, it is interesting to interpret the present findings in terms of the classical chemical bonding theory. The simple Lewis structures corresponding to the ground and first excited states of $\mathrm{C}_{2} \mathrm{H}_{3} \mathrm{X}^{+\cdot}$ can be drawn as Structure 1. The fact that the $\tilde{A}$ state has a very long lifetime means that two different stable charge distributions are possible for $\mathrm{C}_{2} \mathrm{H}_{3} \mathrm{X}^{+\cdot}$ which may be regarded as virtually different entities. Selective generation of a particular charge site/radical site structure and investigation of its reactivity will be very useful to understand the influence of these sites in ionic reactions. For example, the $\alpha$ cleavage and inductive cleavage which are postulated as the major fragmentation pathways in mass spectrometry [43] are the results of the radical and charge site effects.

\section{Conclusions}

We have used the charge exchange method developed recently to judge whether some excited states of monosubstituted ethene cations chosen based on narrow vibrational bandwidths in the photoelectron spectra have long lifetimes. The method has been found simple and decisive in the sense that the long-lived states were located near the recombination energies expected from the photoelectron spectra. $\mathrm{C}_{2} \mathrm{H}_{3} \mathrm{Cl}^{+\cdot}, \mathrm{C}_{2} \mathrm{H}_{3} \mathrm{Br}^{+\cdot}, \mathrm{C}_{2} \mathrm{H}_{3} \mathrm{I}^{+\cdot}$, and $\mathrm{C}_{2} \mathrm{H}_{3} \mathrm{CN}^{+\cdot}$ have been found to possess long-lived excited electronic states, all of which are the $\tilde{\mathrm{A}}^{2} \mathrm{~A}^{\prime}$ states and show well-resolved vibrational structures in the photoelectron spectra. It is interesting to note that these states arise from removal of an electron from the nonbonding $\mathrm{p}_{\|}$orbital of halogen or $\pi(\mathrm{C} \equiv \mathrm{N})_{\|}$of the triple bond. On the other hand, the $\tilde{\mathrm{B}}^{2} \mathrm{~A}^{\prime \prime}$ state of $\mathrm{C}_{2} \mathrm{H}_{3} \mathrm{CN}^{+\cdot}$ which shows a sharp structure in the photoelectron spectrum does not have a long lifetime according to the present results. Present findings are analogous to those found for the benzene derivative cations, that $\tilde{\mathrm{B}}^{2} \mathrm{~B}_{2}$ states of $\mathrm{C}_{6} \mathrm{H}_{5} \mathrm{X}^{+\cdot}(\mathrm{X}=\mathrm{Cl}, \mathrm{Br}, \mathrm{C} \equiv \mathrm{N}$, and $\mathrm{C} \equiv \mathrm{CH})$ have very long lifetimes. These are also the excited electronic states generated by removal of an electron from the $\mathrm{p}_{\|}$orbital of halogen or from the $\pi_{\|}$orbital of triple bond. Exception is the $\tilde{\mathrm{B}}^{2} \mathrm{~B}_{2}$ state of $\mathrm{C}_{6} \mathrm{H}_{5} \mathrm{I}^{+\cdot}$ which was found not to be long-lived unlike the $\tilde{\mathrm{A}}^{2} \mathrm{~A}^{\prime}$ state of $\mathrm{C}_{2} \mathrm{H}_{3} \mathrm{I}^{+}$.

We do not have an explanation why some of the excited electronic states investigated undergo rapid internal conversion while others do not. A thorough theoretical investigation on the nonadiabatic interaction of electronic states involved seems to be needed. 


\section{Acknowledgments}

This work was supported financially by CRI, Ministry of Science and Technology, Republic of Korea. YYY thanks the Ministry of Education for the Brain Korea 21 fellowship.

\section{References}

1. (a) Marcus, R. A. J. Chem. Phys 1952, 20, 364-368. (b) Rosenstock, H. M.; Wallenstein, M. B.; Wahrhaftig, A. L.; Eyring, H. Proc. Nat. Acad. Sci. U.S.A 1952, 38, 667-678.

2. Miller, B. E.; Baer, T. Chem. Phys. 1984, 85, 39-45.

3. Simm, I. G.; Danby, C. J.; Eland, J. H. D. Int. J. Mass Spectrom. Ion Phys. 1974, 14, 285-293.

4. Eland, J. H. D.; Frey, R.; Kuestler, A.; Schulte, H.; Brehm, B. Int. J. Mass Spectrom. Ion Phys. 1976, 22, 155-170.

5. Dannacher, J.; Schmelzer, A.; Stadelmann, J. P.; Vogt, J. Int. J. Mass Spectrom. Ion Phys. 1979, 31, 175-186.

6. Jarvis, G. K.; Boyle, K. J.; Mayhew, C. A.; Tuckett, R. P. J. Phys. Chem. A 1998, 102, 3219-3229.

7. Nishimura, T.; Das, P. R.; Meisels, G. G. J. Chem. Phys. 1986, 84, 6190-6199.

8. Nishimura, T.; Zha, Q.; Meisels, G. G. J. Chem. Phys. 1987, 87, 4589-4597.

9. Weitzel, K. M.; Güthe, F.; Mähnert, J.; Locht, R.; Baumgärtel, H. Chem. Phys. 1995, 201, 287-298.

10. Krailler, R. E.; Russell, D. H. Int. J. Mass Spectrom. Ion Processes 1985, 66, 339-351.

11. Bunn, T. L.; Baer, T. J. Chem. Phys. 1986, 85, 6361-6367.

12. Kim, D. Y.; Choe, J. C.; Kim, M. S. J. Chem. Phys. 2000, 113, $1714-1724$.

13. Won, D. S.; Kim, M. S.; Choe, J. C.; Ha, T. K. J. Chem. Phys. 2001, 115, 5454-5460.

14. Suto, K.; Sato, Y.; Matsumi, Y.; Kawasaki, M. J. Phys. Chem. 1997, 101, 1227-1230.

15. Gilmore, F. R. J. Quant. Spectrom. Radiative Transfer 1965, 5, 369-375.

16. Vrakking, M. J. J.; Villeneuve, D. M.; Stolow, A. J. Chem. Phys. 1996, 105, 5647-5650.

17. Wheeler, M. D.; Newmaz, S. M.; Orrewing, A. J. J. Chem. Phys. 1998, 16, 6594-6605.

18. Nakamura, H.; Kato, S. J. Chem. Phys. 1999, 110, 9937-9947.

19. Bombach, R.; Dannacher, J.; Stadelmann, J. P.; Vogt, J. Chem. Phys. Lett. 1981, 77, 399-402.

20. Biggerstaff, J.; Qian, K.; Howard, S.; Shukla, A.; Futrell, J. Chem. Phys. Lett. 1988, 151, 507-510.

21. Chawla, R.; Krishnamurthy, M.; Shukla, A. K.; Futrell, J. Chem. Phys. Lett. 1999, 301, 531-536.

22. Zhou, X.; Wang, J.; Shukla, A.; Futrell, J. Int. J. Mass Spectrom. 2000, 194, 171-179.

23. Fenistein, S.; Futrell, J.; Heninger, M.; Marx, R.; Mauclaire, G.; Yang, Y. M. Chem. Phys. Lett. 1991, 179, 125-130.
24. Kim, M. S.; Kwon, C. H.; Choe, J. C. J. Chem. Phys. 2000, 113, 9532-9539.

25. Kwon, C. H.; Kim, M. S.; Choe, J. C. J. Am. Soc. Mass Spectrom. 2001, 12, 1120-1126.

26. Youn, Y. Y.; Choe, J. C.; Kim, M. S. submitted.

27. Youn, Y. Y.; Kwon, C. H.; Choe, J. C.; Kim, M. S. J. Chem. Phys. 2002, 117, 2538-2545.

28. Kim, M. S. Int. J. Mass Spectrom. Ion Phys. 1983, 50, 189-203.

29. Sze, K. H.; Brion, C. E.; Katrib, A.; El-Issa, B. Chem. Phys. 1989, 137, 369-390.

30. Locht, R.; Leyh, B.; Hottmann, K.; Baumgärtel, H. Chem. Phys. 1997, 220, 217-232.

31. Hoxha, A.; Locht, R.; Leyh, B.; Dehareng, D.; Hottmann, K.; Baumgärtel, H. Chem. Phys. 2000, 256, 239-249.

32. Kimura, K.; Katsumata, S.; Achiba, Y.; Yamazaki, T.; Iwata, S. Handbook of HeI Photoelectron Spectra of Fundamental Organic Molecules. Japan Scientific Societies Press: Tokyo, 1981, p 182.

33. McDowell, C. A. Mass Spectrometry. McGraw-Hill: New York, 1963; p 7.

34. NIST Standard Reference Database Number 69; (NIST chemistry webbook: July 2001 release).

35. Herod, A. A.; Harrison, A. G.; McAskill, N. A. Can. J. Chem. 1971, 22, 2217-2222.

36. Stockbauer, R.; McCulloh, K. E.; Parr, A. C. Int. J. Mass Spectrom. Ion Phys. 1979, 31, 187-189.

37. Tsai, B. P.; Baer, T.; Werner, A. S.; Lin, S. F. J. Phys. Chem. 1975, 79, 570-574.

38. Watanabe, K.; Nakayama, T.; Mottl, J. J. Quant. Spectrom. Radiative Transfer 1962, 2, 369.

39. Werner, A. S.; Tsai, B. P.; Baer, T. J. Chem. Phys. 1974, 60, 3650-3657.

40. Dibeler, V. H.; Reese, R. M.; Krauss, M. Adv. Mass Spectrom. 1966, 3, 471.

41. Krauss, M.; Walker, J. A.; Dibeler, V. H. J. Res. NBS 1968, 72A, 281.

42. Frisch, M. J.; Trucks, G. W.; Schlegel, H. B.; Scuseria, G. E.; Robb, N. A.; Cheeseman, J. R.; Zakrzewski, V. G.; Montgomery, J. A., Jr.; Stratmann, R. E.; Burant, J. C.; Dapprich, S.; Millam, J. M.; Daniels, A. D.; Kudin, K. N.; Strain, M. C.; Farkas, O.; Tomasi, J.; Barone, V.; Cossi, M.; Cammi, R.; Mennucci, B.; Pomelli, C.; Adamo, C.; Clifford, S.; Ochterski, J.; Petersson, G. A.; Ayala, P. Y.; Cui, Q.; Morokuma, K.; Malick, D. K.; Rabuck, A. D.; Raghavachari, K.; Foresman, J. B.; Cioslowski, J.; Ortiz, J. V.; Stefanov, B. B.; Liu, G.; Liashenko, A.; Piskorz, P.; Komaromi, I.; Gomperts, R.; Martin, R. L.; Fox, D. J.; Keith, T.; Al-Laham, M. A.; Peng, C. Y.; Nanayakkara, A.; Wong, M. W.; Andres, J. L.; Gonzalez, C.; Head-Gordon, M.; Replogle, E. S.; Pople, J. A. GAUSSIAN 98, Revision A.6. Gaussian, Inc.: Pittsburgh, 1998.

43. McLafferty, F. W.; Turec̀ek, F. Interpretation of Mass Spectra. University Science Books: California, 1993; p 51. 